\title{
TUBER CHARACTERISTICS OF DISEASE FREE MERISTEM CLONES OF SOME POTATO GENOTYPES
}

\author{
Gulsum OZTURK*, Zihin YILDIRIM \\ Ege University, Faculty of Agriculture, Department of Field Crops, Izmir, TURKEY \\ *Corresponding author: gulsum.ozturk@ege.edu.tr \\ Received: 02.09.2020
}

\begin{abstract}
Potato seedlings of various potato genotypes free from the following viruses PVS (potato viruses S), PVX (potato viruses X), PVY (potato viruses Y), PLRV (potato leafroll virus), PVA (potato viruses A) and PMTV (potato mop-top viruses) were obtained via meristem culture and they were increased in vitro. Seedlings were grown in the greenhouse and mini tubers obtained were tested in the seed bed and in the field trials.

When the results of greenhouse experiment were evaluated: clone Nif-1 was found to be high for single tuber number (3.0). Clone 6/7-1 had high means as compared to the remaining for single tuber weight $(5.2 \mathrm{~g})$ and single plant yield (14.5 g). The highest mini tuber number was obtained from Clone 6/7 in seedbed experiment. Also Hermes-1 had higher means for single tuber weight and Clone 122-1 had the higher means for plant yield and plot yield than that of other clones. Clones Atlantic-2; 3 and $1(5.8 \mathrm{~cm})$ had high tuber width and clone Hermes-1 and $2(6.6 \mathrm{~cm})$ had the highest means for tuber length in the seedbed trial. Based on the results of field experiment the highest minituber numbers were obtained from Clone 6/7-2 (10.7) and Clone 6/7-2 (10.3). Atlantic-1 (136.5 g) had high mean for tuber weight as compared to other clones. Nif-1 had the highest mean for plant yield as 920.2 g. Clone 122-1 was found to be higher than the other clones for plot yield $(5.3 \mathrm{~kg})$. Clones of Atlantic-1; 2 and $3(5.9 \mathrm{~cm})$ had high tuber width and clones of Juwel-1; 2 and Hermes-2 $(6.8 \mathrm{~cm})$ had the highest means for tuber length.
\end{abstract}

Keywords: Elisa test, meristem culture, minituber, node culture, potato genetic stocks, potatoes clones

\section{INTRODUCTION}

Since potatoes are propagated vegetatively viral infections of potato tubers in the field reduce yield and quality of a potato crop. When the tubers obtained from the field are planted next year as seed potato yields reduce drastically. Therefore meristem cultures have been used widely to obtain virus or disease free potato seed. This technique has been used effectively in seed tuber production (Ali et al., 2013; Mohapatra and Batra, 2017). Knowledge about virus free nature of apical tissue in potato tubers (Quak, 1972) enhanced usage of meristem culture in obtaining stabil potato seed stocks (Ahloowalia, 2000). Pruski (2007) have reported that disease free and genetic uniform potato seed stocks could be obtained by using meristem culture techniques. In seed potato production in vitro techniques have also been used effectively in maintaining genetic sources at the same time (Rosenberg et al., 2013). Ahloowalia (1994) indicated the great advantage of using seed stocks obtained via meristem techniques in producing disease free minitubers as well as genetically stabil seed stocks. Mohapatra and Batra (2017) stressed advantage of the meristem culture from the tissue culture techniques in obtaining disease free potato seed. They reported that the explants of meristem culture could be keep in liquid and half solid media to enhance root and stem development and then could be transferred to greenhouse. The usage of micro propagation techniques has several advantages over traditional seed production. Therefore biotechnological techniques used in certified seed product and conservation of genetic stocks in potato provide great advantages. Ražukas (2002) stressed that the most effective method coping with viral infections as well as fungal and bacterial disease in the potato seed production programs. Approximately 21 virus infections have been reported in potatoes among them especially PLRV, PVX and PVY infections cause high yield reductions (Nagib et al., 2003). These disease factors could easily infect the potato tubers depending on long term usage of seed tubers so cause high yield reduction (Nagib et al., 2003). Therefore potato seed tubers should be renewed periodically. Development of basic potato seed systems and wide application of certified seed usage could provide this requirement. Since virus disease could be prevented by chemically meristem culture system appear to be a suitable approach to obtain virus free plants (Loebenstein et al., 2001; Danci et al., 2012).

Morais et al. (2018) reviewed the usage of meristem culture in preservation of potato genetic stocks. Sarkar and 
Naik (1998) studied the effects of incubation and culture media in the in vitro preservation of four potato genotypes. Maintenance of in vitro selection of genetic material has been considered as an alternative method to the conservation of germplasm of potatoes. Several aspects of in vitro preservation of potato genetic stocks have been studied by workers and this technic has widely been applied accepted (Westeott, 1981a; 1981b; Sarkar and Naik, 1998; Gopal and Chamman, 2010). One of the problems of long term in vitro preservation of the potato is the unexpected changes in the genetic stability (Morais et al., 2018). Since several factors affect the minituber development in the greenhouse or seedbeds; the starting material should be large enough to compensate the losses (Sharma and Pandey, 2013). Al-Ani et al. (2017) growned in vitro plants in cages and they increased minituber weight up to $12 \mathrm{~g}$. In programming of potato conservation program, laboratory, greenhouse and field phases should be combined in right way. Therefore disease free plantlets should be obtained by meristem culture in laboratory. After laboratory maintenance; sample of those plants should be increased in the greenhouse, seedbeds and under field conditions (Novak et al., 1980; Ranalli et al., 1990; Yildirim et al., 2009).

The purpose of this study was to study the tuber characteristics of potato genotypes preserved in the genetic stocks of Department of Field Crops, Ege University in the greenhouse (meristem plants) in the seedbeds and in the field (meristem clones) in a row.

\section{MATERIALS AND METHODS}

This study was conducted in the Tissue Culture Laboratory, greenhouse, seedbed and experimental field of Ege University Faculty of Agriculture in 2016 and in 2018.

\section{Genetic material}

The potato cultivars and clones developed in the Department of Field Crops of the Ege University and some commercial potato varieties tested in the field trial have been used in the study. The certain characteristics of these potato genotypes are given in table 1 .

Table 1. Potato genotype used in the study

\begin{tabular}{ll}
\hline Genotype & \multicolumn{1}{c}{ Known characteristics } \\
\hline Agria & Medium early, long-oval, yellow flesh color, dry matter contents $18.9 \%$, starch $13.7 \%$ \\
Nif & Medium early, round-oval, yellow flesh color, medium eye depth, dry matter contents 23.4 \\
Clone 122 & $\%$, starch $16.8 \%$ \\
Marabel & Short, oval-long, creamy flesh color, dry matter contents $19.6 \%$, starch $13.3 \%$ \\
Royal & Medium early, yellow, oval tuber, starch $14.9 \%$ \\
Hermes & Medium early, oval, yellow \\
Clone 6/7 & Medium late, oval-round, industry type, yellow flesh color, high dry matter contents \\
Atlantic & High yielding, high flower production, FDR mechanism \\
Juwel & Medium early, short-oval tuber, high dry matter contents \\
Agata & Early, high yielding, oval-long-oval consumption type \\
\hline
\end{tabular}

\section{Meristem culture applications}

Apical meristems were taken from 1-2 cm long sprouts starting on March 2, 2016. The MS media (Murashige and Skoog, 1962) + $0.1 \mathrm{mg} / \mathrm{l} \mathrm{IAA} \mathrm{+} 0.1 \mathrm{mg} / \mathrm{l} \mathrm{BAP}+0.1 \mathrm{mg} / \mathrm{l}$ $\mathrm{GA}_{3}$ was prepared as described by Yildirim and Yildirim (1984) and meristem cuts were taken. Apical meristems were taken from surface sterilized potato sprouts and they were left to development (Ozturk and Yildirim, 2014). Meristem cuts were done until April and 60 in vitro plantlets were obtained. Standard Elisa test was applied for PVS, PVX, PVY, PLRV, PVA and PMTV to these plantlets originated from meristems and 18 plantlets were selected as virus free. The plantlets of these selected clones were used as disease free genetic material in the study.

\section{Micropropagation and increasing of in vitro plantlets}

Micropropagations of disease free meristem plantlets were done in $\mathrm{MS}+2 \mathrm{mg} / \mathrm{l}$ IBA medium as described by Yildirim (1995). Three subcultures of selected 18 potato clones were kept in vitro and developed clones were transferred to greenhouse when they reached to $4-5 \mathrm{~cm}$ following acclimatization. 

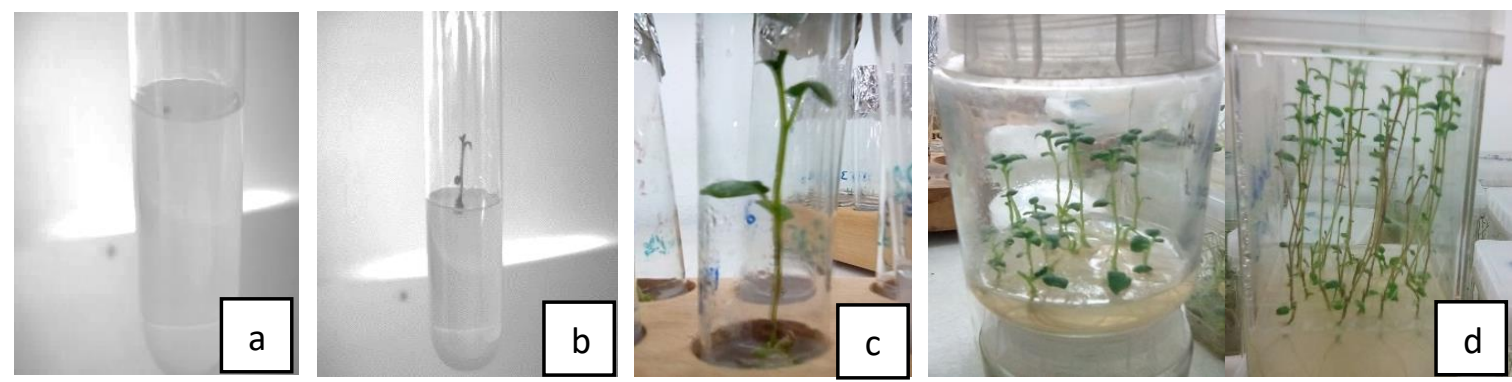

Figure 1. a) Apical meristem b) In vitro plantlets c) Development of in vitro plantlets d) Micropropagation

\section{Minituber production from in vitro plantlets in greenhouse}

Disease free in vitro 18 clones originated from meristem culture were planted in plastic pots containing 2:1 soil:turf mixture. Greenhouse study was arranged in Completely Randomized Design (CRD) in 3 replications and planting was completed in February, 2017. In vitro plantlets were hoed three times and irrigated regularly per week by the growing period. The Elisa test was applied by using leaves of plants and all of the clones were found to be free of viruses. The plants were harvested on May 21, 2017 by hand and minitubers in were obtained. Tuber number, single tuber weight $(\mathrm{g})$ and single plant yield $(\mathrm{g})$ of harvested plants were measured and additional virus testing was applied.

\section{Growing minitubers in seedbeds}

Following the dormancy period minitubers were grown in the seedbed trial. The experiment was arranged in Completely Randomized Design (CRD) with 3 replications. One single row plot $1.5 \mathrm{~m}$ long and $50 \mathrm{~cm}$ apart and $30 \mathrm{~cm}$ spacing on the row was used. Planting was done on August 24, 2017 by hand. Two hilling and irrigations of potato growing were applied during the growing period. The trial was harvested on December 18, 2017 by hand. Observation and visual disease tests were done on the harvested tubers. Tuber number, single tuber weight $(\mathrm{g})$, plant yield $(\mathrm{g})$, plot yield $(\mathrm{kg})$, tuber width $(\mathrm{cm})$ and tuber length $(\mathrm{cm})$ were measured and recorded.

\section{Field trial of minitubers}

Field trial of disease free minitubers obtained in the seedbed trials were grown in the field trial. The climatical data pertinent to the experimental field are given in Table 2. The soil of the experimental field was alluvial, rich in marl, $\mathrm{pH}$ of the medium was alkali; low for salt and medium rich for nitrogen and rich for potassium. The design of the trial was Randomized Complete Block Design (RCBD) with 3 replications. Plot size was 1 row in 3 meters length. Spacings were $70 \mathrm{~cm}$ between rows and $30 \mathrm{~cm}$ on the row. Planting was done on March 24, 2018 by hand. The trial was harvested on June 29, 2018 by hand. The following tuber traits were measured: tuber number, single tuber weight $(\mathrm{g})$, plant yield $(\mathrm{g})$, plot yield $(\mathrm{kg})$, tuber width $(\mathrm{cm})$ and tuber length $(\mathrm{cm})$.
Table 2. Temperature $\left({ }^{\circ} \mathrm{C}\right)$ and total precipitation $(\mathrm{mm})$ during the experimental period in Bornova-İzmir, Turkey*

\begin{tabular}{lll}
\hline Years/Months & Temperature $\left({ }^{\mathbf{C}} \mathbf{C}\right)$ & $\begin{array}{l}\text { Total } \\
\text { Precipitation } \\
(\mathbf{m m})\end{array}$ \\
\hline $\mathbf{2 0 1 6}$ & & \\
\hline March & 13.8 & 102.8 \\
April & 18.9 & 12.8 \\
May & 21.2 & 28.2 \\
June & 27.7 & 9.2 \\
July & 29.9 & 1.2 \\
& & \\
\hline 2017 & & \\
\hline August & 29.4 & 0.3 \\
September & 24.6 & 0.9 \\
October & 18.8 & 45.7 \\
November & 13.3 & 62.1 \\
December & 11.8 & 73.9 \\
\hline 2018 & & \\
\hline January & 9.1 & 58 \\
February & 12.1 & 116.8 \\
March & 15.8 & 67.2 \\
April & 19.3 & 11.3 \\
May & 23.9 & 67.6 \\
June & 26.8 & 29.8 \\
July & 29.7 & 0.3 \\
\hline : & &
\end{tabular}

*: taken from Bornova Meteorological Station

\section{Statistical analyses}

The data obtained in the trials run in the greenhouse, seedbeds and field in 2017, 2018 were analyzed by using the standard analysis of variance (Acikgoz et al., 2004). The means were compared by using the least significant difference (LSD) at $\mathrm{p} \leq 0.05$ level as described by (Steel and Torrie, 1980).

\section{RESULTS AND DISCUSSION}

The means of tuber traits measured in the greenhouse are shown in Table 3. The results based on seedbed growing are given in Table 4 . The means of the clones grown in the field trial are given in Table 5. 
Table 3. Means of the tuber characteristics of meristem plants grown in the greenhouse in 2017

\begin{tabular}{llll}
\hline Clone & Tuber number & Single tuber weight (g) & Single plant yield (g) \\
\hline Agata-1 & 2.3 & 3.9 & 8.9 \\
Agata-2 & 2.3 & 3.8 & 8.7 \\
Nif-1 & $\mathbf{3 . 0}$ & 3.3 & 9.7 \\
Clone 6/7-1 & 2.7 & 5.1 & 13.7 \\
Clone 6/7-2 & 2.8 & $\mathbf{5 . 2}$ & $\mathbf{1 4 . 5}$ \\
Royal-1 & 2.8 & 4.7 & 13.2 \\
Royal-2 & 2.8 & 4.8 & 13.2 \\
Royal-3 & 2.8 & 4.7 & 13.2 \\
Atlantic-1 & 2.5 & 4.2 & 10.3 \\
Atlantic-2 & 2.4 & 4.3 & 10.4 \\
Atlantic-3 & 2.4 & 4.3 & 10.4 \\
Juwel-1 & 2.0 & 4.6 & 9.2 \\
Juwel-2 & 2.0 & 4.6 & 9.2 \\
Hermes-1 & 2.7 & 3.1 & 8.3 \\
Hermes-2 & 2.7 & 3.1 & 8.4 \\
Marabel-1 & 2.1 & 3.6 & 7.6 \\
Clone 122-1 & 2.5 & 3.4 & 8.5 \\
Agria-1 & 2.0 & 4.6 & 9.2 \\
\hline LSD $(0.05)$ & 0.317 & 0.371 & 1.272 \\
\hline F & $7.970^{* *}$ & $26.717^{* *}$ & $24.319^{* * *}$ \\
\hline **: significant at the $\mathrm{p} \leq 0.01$ probability level & & \\
\hline
\end{tabular}

Table 4. Means of the tuber characteristics of meristem clones grown in the seedbeds in 2017

\begin{tabular}{lllllll}
\hline Clones & $\begin{array}{l}\text { Tuber } \\
\text { number }\end{array}$ & $\begin{array}{l}\text { Single tuber } \\
\text { weight }(\mathbf{g})\end{array}$ & $\begin{array}{l}\text { Plant yield } \\
(\mathbf{g})\end{array}$ & $\begin{array}{l}\text { Plot yield } \\
(\mathbf{k g}\end{array}$ & $\begin{array}{l}\text { Tuber width } \\
(\mathbf{c m})\end{array}$ & $\begin{array}{l}\text { Tuber length } \\
(\mathbf{c m})\end{array}$ \\
\hline Agata-1 & 6.0 & 53.3 & 319.7 & 1.6 & 4.2 & 5.5 \\
Agata-2 & 6.0 & 54.1 & 324.4 & 1.6 & 4.2 & 5.5 \\
Nif-1 & 5.0 & 101.5 & 507.4 & 1.9 & 5.0 & 6.0 \\
Clone 6/7-1 & $\underline{\mathbf{8 . 0}}$ & 72.1 & 603.7 & 1.7 & 5.0 & 5.4 \\
Clone 6/7-2 & $\underline{\mathbf{8 . 0}}$ & 72.4 & 577.1 & 1.8 & 5.0 & 5.4 \\
Royal-1 & 6.0 & 85.1 & 510.6 & 1.9 & 5.1 & 6.3 \\
Royal-2 & 6.0 & 83.8 & 515.9 & 1.5 & 5.1 & 6.3 \\
Royal-3 & 6.0 & 85.1 & 510.0 & 1.6 & 5.1 & 6.3 \\
Atlantic-1 & 5.0 & 105.7 & 528.5 & 1.9 & $\underline{\mathbf{5 . 8}}$ & 6.3 \\
Atlantic-2 & 5.0 & 104.5 & 522.4 & 1.9 & $\underline{\mathbf{5 . 8}}$ & 6.3 \\
Atlantic-3 & 5.0 & 103.8 & 519.2 & 1.9 & $\underline{\mathbf{5 . 8}}$ & 6.4 \\
Juwel-1 & 4.0 & 63.3 & 252.0 & 1.5 & 4.5 & 6.4 \\
Juwel-2 & 4.0 & 63.0 & 253.3 & 1.5 & 4.5 & 6.4 \\
Hermes-1 & 6.2 & $\underline{\mathbf{1 0 9 . 5}}$ & 700.5 & 1.9 & 5.4 & $\underline{\mathbf{6 . 6}}$ \\
Hermes-2 & 6.2 & 107.7 & 697.8 & 1.9 & 5.4 & $\underline{\mathbf{6 . 6}}$ \\
Marabel-1 & 5.0 & 98.3 & 491.8 & 2.0 & 4.8 & 6.0 \\
Clone 122-1 & 7.5 & 97.9 & $\underline{\mathbf{7 3 4 . 5}}$ & $\underline{\mathbf{2 . 2}}$ & 5.6 & 6.4 \\
Agria-1 & 5.5 & 62.5 & 343.9 & 1.7 & 4.6 & 5.8 \\
\hline LSD $(0.05)$ & 0.159 & 4.138 & 31.014 & 0.098 & 0.064 & 0.078 \\
F & $434.706^{* *}$ & $187.729^{* *}$ & $182.590^{* *}$ & $36.032^{* *}$ & $552.412^{* *}$ & $237.319^{* *}$ \\
\hline$* *$ significant at the $\mathrm{p} \leq 0.01$ & probability level & & & & &
\end{tabular}

\section{Evaluation of the tuber characteristics of potato clones grown in the greenhouse in 2017}

The tuber characteristics of clones grown in greenhouse had highly significant $\mathrm{F}$ values indicating considerably variation for tuber number, single tuber weight $(\mathrm{g})$ and single plant yield $(\mathrm{g})$. When the means of the clones compared for tuber number; clone Nif 1 had the highest value (3.0). Royal-1; 2 and 3 clones and Clone 6/7-2 (2.8) were followed clone Nif-1. The lowest mean for tuber number such as 2.0 were obtained from Juwel-1;
2 and Agria-1 clones. Ahloowalia (1999) reported tuber number such as 5 for Pontiac and Ozturk and Yildirim (2011) reported tuber number between 2.6-3.0 for Hermes. In addition, Ozturk and Yildirim (2014) reported tuber numbers of 2.7 and 2.8 for Agria and average 1.82.0 tubers for Hermes. Al-Ani et al. (2018) reported average tuber numbers such as 3.2 and 3.1 for Burren and Emma genotypes. The tuber numbers found in our study were in agreement with the means reported by those workers. Awati et al. (2018) reported average 2-3 minitubers from the potato clones grown in soil : sand 
media. In our study standard soil: turf mixtures were used which were similar to their procedures. Among the potato meristem clones tested cultivar Nif released by our Department and one departmental in selected Clone 6/7 had high tuber number capacity. Especially Clone 6/7 also had similar results in an earlier study (Ozturk and Yildirim, 2018).

When means of single tuber weight were compared (Table 3) Clone 6/7-2 and Clone 6/7-1 had highest means such as $5.2 \mathrm{~g}$ and $5.1 \mathrm{~g}$ respectively. Royal-2 (4.8 g); Royal-1 (4.7 g) clones followed this genotype. The lowest single plant yield was obtained from clones Hermes- 1 and 2 as 3.1 g. Ahloowalia (1994) has reported that the minituber production was related to genotype and ranging between 1.3-2.8 g. Struik (2007) stated the possibility of obtaining minituber with single tuber weight between 0.1 and $10 \mathrm{~g}$. Ozturk and Yildirim (2011) reported $4.3 \mathrm{~g}$ and $4.0 \mathrm{~g}$ means for Granola and Hermes under greenhouse conditions. They also reported similar single tuber weight for Agria and Hermes in another study (Ozturk and Yildirim, 2014). Non significant means found among the clones of the genotypes could be accepted in close agreement with these earlier reports.

When the means of single plant yields were evaluated (Table 3). The highest means were for Clone 6/7-2 (14.5 g) and Clone 6/7-1 (13.7 g). Royal-3; Royal-2 and Royal1 clones followed them $(13.2 \mathrm{~g})$. The lowest mean for single plant yield was obtained from Marabel-1 (7.6 g). Ranalli et al. (1990) reported that single plant yield was varied in the range of 0.4-4.4 g. Ahloowalia (1999) has reported single plant yield as $4.8 \mathrm{~g}$ in the greenhouse study. He also reported single plant yield variation in the $0.5 \mathrm{~g}$-17.3 g range (Ahloowalia, 1994). Ozturk (2017) reported the single plant yield means between $3.3 \mathrm{~g}$ and 10.7 g. Al-Ani et al. (2017) reported $10.1 \mathrm{~g}$ single plant yield for Burren genotype as well as $7.2 \mathrm{~g}$ for Emma genotype. The single plant yields obtained in our study were found between $7.6 \mathrm{~g}-14.5 \mathrm{~g}$ and they could be accepted in agreement with these earlier reported means.

\section{Evaluation of tuber characteristics of potato meristem clones grown in the seedbeds}

It could be seen in table 4 that variations for the tuber characteristics studied were highly significant at the $\mathrm{p} \leq 0.01$ probability level. Means of tuber numbers indicated that Clone 6/7-2 and 6/7-1 had the highest tuber number (8.0). Clone 122-1 has followed it with a mean of 7.5 tubers. Juwel-1 and Juwel-2 clones had the lowest means (4.0). Ozkaynak and Samanci (2005) reported that tuber number of Marabel was changed between 2 and 5 tubers. Ozturk (2017) has reported that mean tuber number has changed between 5 and 8.9. Our results were in agreement with their results.

When the means of single tuber weight of meristem clones were compared clone Hermes- 1 had high mean such as $109.5 \mathrm{~g}$ and clones Atlantic-1, 2, 3 and clone Nif-1 also had high mean such as over $100 \mathrm{~g}$. The lowest single tuber weights were obtained from clones Agata-2 (54.1 g) and Agata-1 (53.3 g). Ozturk (2017) has grown seedlings in the seedbeds instead of greenhouse and Hermes genotype resulted in $3.33 \mathrm{~g}$ single tuber weight. In this study meristem clones were grown in the greenhouse first and then minitubers obtained were grown in the seedbeds. Single tuber weight of Hermes genotype had as high as $109.5 \mathrm{~g}$ means were obtained in the seedbeds. This indicates the possibility of increasing tuber weight by applying standard greenhouse and seedbed propagation to compensate low yields in potato yield trials in comparison to normal seed tubers.

Clone 122-1 had the highest mean for single plant yield (734.5 g). Clones Hermes-1 and Hermes-2 had also high single plant yields such as $700.5 \mathrm{~g}$ and $697.8 \mathrm{~g}$ respectively. Clone 6/7-1 and Clone 6/7-2 had also high single plant yields such as $603.6 \mathrm{~g}$ and $577.1 \mathrm{~g}$ respectively. The lowest mean for plant yield was obtained from Juwel-2 (253.3 g) and Juwel-1 (252.0 g). Ahloowalia (1999) reported $562 \mathrm{~g}$ plant yield for variety Spunta. Vinterhalter (2008) has stressed the usage of $50 \mathrm{~g}$ $70 \mathrm{~g}$ tubers as standard seed tuber to obtain high plant yields. In this study tubers of $5 \mathrm{~g}$ and over were used and means of tuber weight were found to be close suitable to standard seed tuber weight.

When the means of plot yields for meristem clones were compared (Table 4). Clone 122-1 had the highest plot yield such as $2.2 \mathrm{~kg}$. Marabel-1 $(2.0 \mathrm{~kg}$ ) followed this clone. The lowest plot yield was obtained from Juwel-1 and Juwel-2 and Royal-2 clones between $1.3 \mathrm{~kg}$ and 1.5 $\mathrm{kg}$. It could be seen in Table 4 that clones of Atlantic-2, 3 and 1 had the highest tuber width with $5.8 \mathrm{~cm}$. Clone $122-$ 1 had followed these genotypes with a mean of $5.6 \mathrm{~cm}$. The lowest tuber width such as $4.2 \mathrm{~cm}$ was obtained from Agata- 1 and 2 clones. The highest means for tuber length was obtained from clones Hermes-1 and Hermes-2 (6.6 $\mathrm{cm})$. The lowest means of tuber length were obtained for Clones 6/7-1 and Clone 6/7-2 as $5.4 \mathrm{~cm}$. Tubers with 35 $\mathrm{mm}-55 \mathrm{~mm}$ were used in certified seed potato production (Ahloowalia, 1994). The tubers obtained in our study were in suitable size and free of diseases so they can be distributed to growers after increasing 1 and 2 years in the field. Struik (2007) has reported that tubers in $5 \mathrm{~mm}-25$ $\mathrm{mm}$ sizes could be used to obtained minitubers in seed potato production. 
Table 5. Mean of the tuber characteristics of clones measured in the field trial run in 2018.

\begin{tabular}{lllllll}
\hline Clone & $\begin{array}{l}\text { Tuber } \\
\text { number }\end{array}$ & $\begin{array}{l}\text { Single tuber } \\
\text { weight }(\mathbf{g})\end{array}$ & $\begin{array}{l}\text { Plant yield } \\
(\mathbf{g})\end{array}$ & $\begin{array}{l}\text { Plot yield } \\
(\mathbf{k g})\end{array}$ & $\begin{array}{l}\text { Tuber width } \\
(\mathbf{c m})\end{array}$ & $\begin{array}{l}\text { Tuber length } \\
(\mathbf{c m})\end{array}$ \\
\hline Agata-1 & 7.3 & 92.0 & 673.3 & 3.6 & 4.4 & 5.8 \\
Agata-2 & 8.0 & 81.0 & 648.0 & 3.5 & 4.4 & 5.8 \\
Nif-1 & 7.7 & 120.2 & $\underline{\mathbf{9 2 0 . 2}}$ & 4.1 & 5.3 & 6.1 \\
Clone 6/7-1 & $\underline{\mathbf{1 0 . 3}}$ & 87.7 & 905.0 & 3.3 & 5.1 & 5.6 \\
Clone 6/7-2 & $\underline{\mathbf{1 0 . 7}}$ & 87.3 & 901.3 & 3.6 & 5.1 & 5.6 \\
Royal-1 & 6.3 & 95.0 & 610.0 & 3.3 & 5.1 & 6.5 \\
Royal-2 & 6.3 & 95.3 & 602.0 & 3.1 & 5.4 & 6.5 \\
Royal-3 & 6.3 & 92.0 & 581.3 & 3.1 & 5.3 & 6.5 \\
Atlantic-1 & 6.3 & $\underline{\mathbf{1 3 6 . 5}}$ & 862.1 & 4.4 & $\underline{\mathbf{5 . 9}}$ & 6.5 \\
Atlantic-2 & 6.3 & 116.0 & 747.3 & 4.0 & $\underline{\mathbf{5 . 9}}$ & 6.5 \\
Atlantic-3 & 6.7 & 126.3 & 847.4 & 4.3 & $\underline{\mathbf{5 . 9}}$ & 6.5 \\
Juwel-1 & 6.7 & 104.2 & 691.3 & 3.8 & 4.8 & $\underline{\mathbf{6 . 8}}$ \\
Juwel-2 & 6.7 & 92.2 & 680.3 & 3.7 & 4.8 & $\underline{\mathbf{6 . 8}}$ \\
Hermes-1 & 8.0 & 94.2 & 753.9 & 3.5 & 5.5 & 6.7 \\
Hermes-2 & 8.0 & 94.0 & 752.3 & 3.4 & 5.6 & $\underline{\mathbf{6 . 8}}$ \\
Marabel-1 & 5.7 & 115.2 & 561.8 & 4.4 & 5.0 & 6.1 \\
Clone 122-1 & 8.5 & 107.7 & 897.9 & $\underline{\mathbf{5 . 3}}$ & 5.7 & 6.6 \\
Agria-1 & 6.0 & 88.3 & 529.0 & 3.5 & 5.0 & 6.0 \\
\hline LSD $(0.05)$ & 0.990 & 10.222 & 79.559 & 0.136 & 0.110 & $148.022^{* *}$ \\
F & $16.760^{* *}$ & $18.969^{* *}$ & $22.248^{* *}$ & $134.728^{* *}$ & $181.502^{* *}$ \\
\hline ** significat
\end{tabular}

\section{Evaluation of tuber characteristics of potato meristem} clones grown in the field trial

The $\mathrm{F}$ values for the tuber traits given in Table 5 indicated that the variation for tubers traits of 18 clones were highly significant at the $\mathrm{p} \leq 0.01$ probability level. Clone 6/7-1 and Clone 6/7-2 had the highest means for tuber number such as 10.7 and 10.3 respectively. Clone 122-1 had followed them with a mean of 8.5. The lowest mean for tuber number was for Marabel-1 (5.7). Ranalli et al. (1990) reported 6.4 tubers in $28 \mathrm{~mm}-45 \mathrm{~mm}$ range similar to our results.

Clone Atlantic-1 had high mean for single tuber weight $(136.5 \mathrm{~g})$. The lowest single tuber weight was obtained from Agata-2 (81.0 g). Ranalli et al. (1990) have reported single tuber weight as $75.7 \mathrm{~g}$. Ahloowalia (1994) has also reported $12.1 \mathrm{~g}$ and $17.3 \mathrm{~g}$ single tuber weights for Desire and Spunta. Single tuber weight obtained in our study were higher than those reported values.

When plant yield means of the meristem clones were compared (Table 5) clone Nif-1 had the highest mean such as 920.2 g, Clone 6/7-1 (905.0 g) and Clone 6/7-2 (901.3 g) and Clone 122-1 (897.9 g) and Atlantic-1 (862.1 g) had also high means for plant yield means following Nif-1. The lowest mean for plant yield was obtained from Agria1 (529.0 g).

Clone 122-1 had the highest mean for plot yield (5.3 $\mathrm{kg}$ ). Marabel-1 had $4.4 \mathrm{~kg}$ plot yield after this clone. The lowest plot yield was obtained from Royal-3 and Royal-2 (3.0 kg). Ozkaynak and Samanci (2005) reported the suitability of minitubers obtained from greenhouse and seedbed propagation. In this study we also have to obtain minitubers in required sizes. For example we have grown
$5 \mathrm{~g}$ minitubers and obtained $30 \mathrm{~g}$ minitubers in the seedbeds.

Clones Atlantic-1, 3 and 2 had the highest tuber width such as $5.9 \mathrm{~cm}$ (Table 5). Agata-1 and Agata-2 had the lowest means for tuber width. Juwel- 1 and 2 clones and clone Hermes- 2 had the highest tuber length was for clones $6 / 7-1$ and $6 / 7-2$ as $5.6 \mathrm{~cm}$.

\section{CONCLUSION}

Based on discussion of results, the following conclusions could be drawn:

1- Before using potato genetic stocks maintained in the laboratory; they should be increased and compared as meristem clones in the greenhouse, in the seedbeds and in the field trial in a row.

2- Disease free meristem clones derived from genetic stocks had suitable minitubers in size during the seedbed increases with high single tuber weight (109.5 g), plant yield $(734.5 \mathrm{~g})$ and plot yield $(2.2 \mathrm{~kg})$. Therefore they can be utilized in production of seed tubers to be used in the field trials.

3- To make a final decision standard seed tubers should be included in the field trial as control. Or one more field trials should be run to obtain optimum size tubers.

\section{ACKNOWLEDGEMENTS}

The study was supported by Ege University Scientific Research Projects Board (Project number: 2016-ZRF-035 number). The authors would like to appreciate and thank to the financial support. 


\section{LITERATURE CITED}

Ahloowalia, B.S. 1994. Production of mini-seed tubers using a modular system of plant micropropagation. Potato Research 42: 569-575.

Ahloowalia, B.S. 1999. Production and performance of potato mini-tubers. Euphytica 75: 163-172.

Ahloowalia, B.S. 2000. Stability of micropropagated plants and mini-tubers of potato, Proceedings of the International Symposium on Methods and Markers for Quality Assurance in Micropropagation Symposium 4\& Cloning Strategies, (Eds. B.M Doyle, R.F. Curry, \& A.C. Cassells), Department of Plant Science, National University of Ireland, Cork 24.

Al-Ani, M., W.A. Abdulmajed, E.A.J. El-Kaaby, A.M. Ibrahim, F. Naser, A. Redha, M. Ahmed, S. Abdalzahra. 2017. Field performance evaluation of two potatoes (Solanum tuberosum L.) cultivars propagated in vitro. International Journal of Multidisciplinary and Current Research ISSN: 2321-3124.

Ali, M.A., K.M. Nasiruddin, M.S. Haque, S.M. Faisal. 2013. Virus elimination in potato through meristem culture followed by thermotherapy. SAARC J. Agri. 11(1): 71-80.

Awati, R., A. Bhattacharya, B. Char. 2018. Rapid multiplication technique for production of high-quality seed potato (Solanum tuberosum L.) tubers. Journal of Applied Biology\&Biotechnology (available online: http://www.jabonline. in)

Danci, M., D. Oana, M. Luiza, B. Anca, O. Daniela, P. Cerasela, F. Berbentea, I. David. 2012. Production of virus free potato plantlets. Journal of Horticulture. Forestry and Biotechnology 16(1): 232-238.

Gopal, J. and N.S. Chamman. 2010. Slow growth in vitro conservation of potato germplasm at low temperatue. Potato Research 53: 141-149.

Loebenstein, G., P.H. Berger, A.A. Brunt, R.H. Lawson. 2001. Virus and virus-like disease of potatoes and production of seed potatoes. Kluwer Academic Publishers, Dordrecht, Olando.

Mohapatra, P.P. and V.K. Batra. 2017. Tissue culture of potato (Solanum tuberosum L.): a review. Int. J. Curr. Microbiol. App. Sci. 6(4): 489-495.

Morais, T.P., S.A. Asmar, J. Silva, Q. Luz, B. Melo. 2018. Application of tissue culture techniques in potato. Biosci. J. 34(49): 952-969.

Murashige, T. and F. Skoog. 1962. A revised medium for rapid growth and bioassay with tobacco cultures. Physiol. Plant. 15: 473-479.

Nagib, A., S.A. Hossain, M.F. Alam, M.M. Hossain, R. Islam, R.S. Sultana. 2003. Virus free potato tuber seed production through meristem culture in Tropical Asia. Asian Journal of Plant Sciences 2(8): 616-622.

Novak, F.J., J. Zadina, V. Horackova and I. Maskova. 1980. The effect of growth regulators on meristem tip development and in vitro multiplication of Solanum tuberosum L. plants. Potato Research 23(2): 155-166.

Ozkaynak, E. and B. Samanci. 2005. Yield and yield components of greenhouse, field and seedbed grown potato (Solanum tuberosum L.) plantlets. Journal of Akdeniz University. 18: 125-129.
Ozturk, G. and Z. Yildirim. 2011. Uniformity of potato minitubers derived from meristem cultures of nuclear seed stocks. Turkish Journal of Field Crops 16: 149-152.

Ozturk, G. and Z. Yildirim. 2014. Comparison of old and new clones of potato nuclear seed stocks for tuber uniformity in the greenhouse. Turkish Journal of Field Crops 19: 90-95.

Ozturk, G. 2017. Comparison of minitubers of in vitro potato seedlings in seedbed conditions, $5^{\text {th }}$ International Molecular Biology and Biotechnology Congress. 25-19 August 2016, Macedonia.

Ozturk, G. and Z. Yildirim. 2018. Production of potato clones through crossing suitable to the conditions of the Ege Region. Project Final Report No: 2014-ZRF-052 (in Turkish).

Pruski, K. 2007. The canon of potato science: in vitro multiplication through nodal cuttings. Potato Research 50: 293-296.

Quak, F. 1972. Therapy, (virusses of potatoes and seed potato production Edi.J.A. de Box), Pudok, Wageningen-Holland, 158-166 pp.

Ranalli, P., E. Forti, G. Mandolino, B. Casarini. 1990. Improving production and health of seed potato stocks in Italy. Potato Research 33: 377-387.

Ražukas, A. 2002. Effect of genotype on distribution of diseases and viruses in potato. Biologija, ISSN: 1392-0146, Nr.1

Roosenberg, V., J. Edesi, K. Liiv, K. Kotkas. 2013. Overview of in vitro preservation of potato and use of the gene bank material in Estonia. Proceedings of the Latvian Academy of Sciences 67: 219-223.

Sarkar, D. and P.S. Naik. 1998. Factors affecting minimal growth conservation of potato micro pants in vitro. Euphytica 102: 275-280.

Sharma, A.K. and K.K. Pandey. 2013. Potato minituber production through direct transplanting of in vitro plantlets in green or screen houses- a review. Potato J. 40(2): 95-103.

Steel, R.G.D. and J.H. Torrie. 1980. Principles and Procedures of Statistics. McGaw-Hill Book Company, Inc. N.Y.

Struik, P. 2007. The canon of potato science: minitubers. Potato Research 50: 305-308.

Vinterhalter, D. 2008. Potato in vitro culture technique and biotechnology. Fruit, Vegetable and Cereal Science and Biotechnology 2 (special issue 1): 17-45.

Yildirim, M.B. and Z. Yildirim. 1984. Research on obtaining virus-free potato seeds through meristem culture. Journal of Ege University Faculty of Agriculture 21:45-50 .

Yildirim, Z. 1995. (Solanum tuberosum L.) In vitro tuber production. Journal of Ege University Faculty of Agriculture 32:73-77 (in Turkish).

Yildirim, Z. 1995. Mini tuber production from potato seedlings. Journal of Ege University Faculty of Agriculture 32: 91-97 (in Turkish).

Yildirim, Z., S. Erkan, M. Gumus. 2009. Development of national seed potato systems. Public Project-TUBITAK, TOVAG (in Turkish).

Wescott, R. 1981a. Tissue culture storage of potato germplasm 1. minimal growth storage. Potato Research 24: 331-342.

Wescott, R. 1981b. Tissue culture storage of potato germplasm 2. use of growth retarders. Potato Research 24: 343-352. 